\title{
Lanostane-Type Triterpenoids from Scilla scilloides and Structure Revision of Drimiopsin D
}

\author{
Fu-Cai Ren $\cdot$ Li-Xia Wang $\cdot$ Qin Yu • \\ Xian-Jun Jiang $\cdot$ Fei Wang
}

Received: 18 August 2015/ Accepted: 28 September 2015/Published online: 12 October 2015

(C) The Author(s) 2015. This article is published with open access at Springerlink.com

\begin{abstract}
Two hitherto unknown lanostane-type triterpenoids, namely scillascillol (1) and scillascillone (2), and a hitherto unknown norlanostane-triterpene glycoside, namely scillascilloside B-1 (3), were isolated from the ethanol extract of the whole plants of Scilla scilloides. Their structures were elucidated on the basis of extensive spectroscopic studies. In addition, the structure of drimiopsin D (6a) has been revised as 2,5-dimethoxy-8-methyl-1,3,6-trihydroxyxanthone (6) by reanalysis of the spectroscopic data.
\end{abstract}

Graphical Abstract

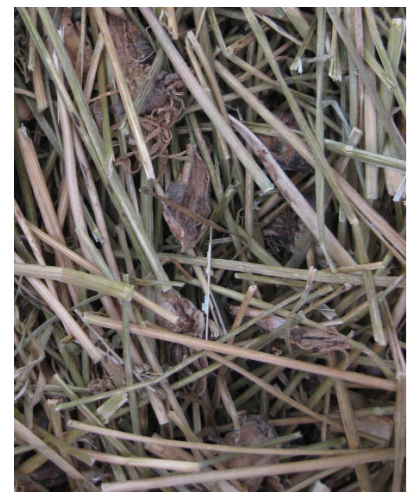

Scilla scilloides

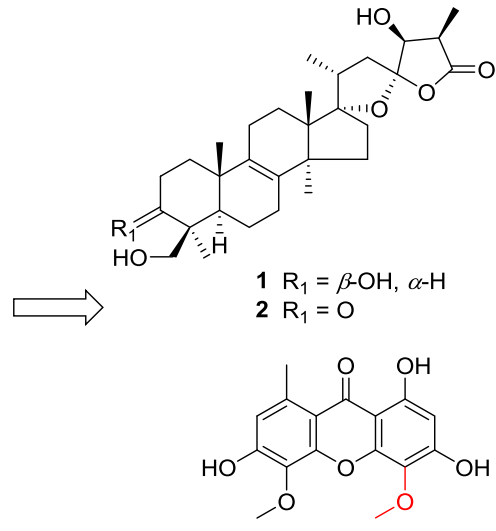

6a

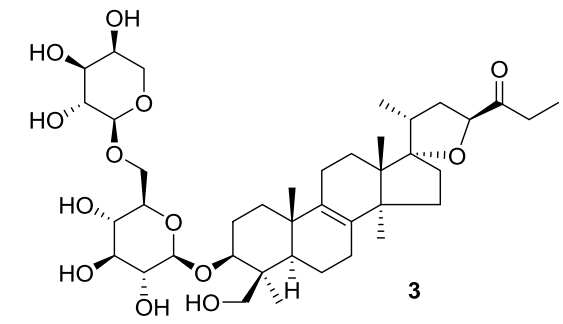

$\stackrel{\text { revised }}{\longrightarrow}$

6

Keywords Scilla scilloides $\cdot$ Lanostane $\cdot$ Scillascillol $\cdot$ Scillascillone $\cdot$ Structure revision

Electronic supplementary material The online version of this article (doi:10.1007/s13659-015-0076-0) contains supplementary material, which is available to authorized users.

F.-C. Ren · L.-X. Wang · Q. Yu · X.-J. Jiang · F. Wang ( $ه)$ BioBioPha Co., Ltd., Kunming 650201, People's Republic of China

e-mail: f.wang@mail.biobiopha.com

\section{Introduction}

Scilla scilloides (Lindl.) Druce is a perennial herb belonging to the Liliaceae family, also compiled in Hyacinthaceae family in the relatively new classification system [1]. The bulbs or the whole plants have been used as a foodstuff, a traditional Chinese medicine for promoting blood circulation, an analgesic, an anti-inflammatory agent, 

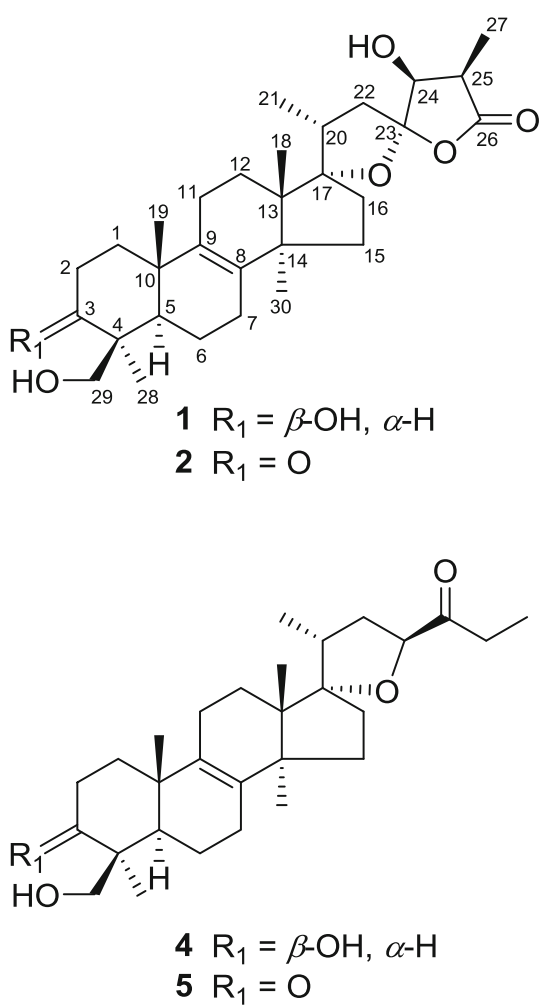

Fig. 1 Structures of compounds 1-8

and treatment of heart failure and arrhythmia [2]. Previous chemical investigations on $S$. scilloides reported homoisoflavones, lanostane-type and norlanostane-type triterpenoids, xanthones, lignans, etc. [3-10]. As part of a BioBioPha (http://www.chemlib.cn) objective to assemble a large-scale natural product library valuable in the discovery of new drug leads from nature [11-14], the phytochemical investigation on the whole plants of S. scilloides led to isolation of two new lanostane-type triterpenoids, namely scillascillol (1) and scillascillone (2), a new norlanostane-triterpene glycoside, namely scillascilloside B-1 (3), together with two known norlanostanes, 15-deoxoeucosterol (4) [4] and 3-dehydro-15-deoxoeucosterol (5) [4], and three known xanthones, drimiopsin D (6) [15], drimiopsin C (7) [15] and norlichexanthone (8) [16] (Fig. 1). This paper describes the isolation and structural elucidation of new lanostane-type triterpenoids and structure revision of a xanthone drimiopsin D.

\section{Results and Discussion}

Compound $\mathbf{1}$ was obtained as a white amorphous powder. Its molecular formula was determined to be $\mathrm{C}_{30} \mathrm{H}_{46} \mathrm{O}_{6}$ on the basis of negative-ion HRESIMS at $m / z, 501.3207[\mathrm{M}-\mathrm{H}]^{-}$ (calcd for $\mathrm{C}_{30} \mathrm{H}_{45} \mathrm{O}_{6}, 501.3216$ ). The IR absorption bands at

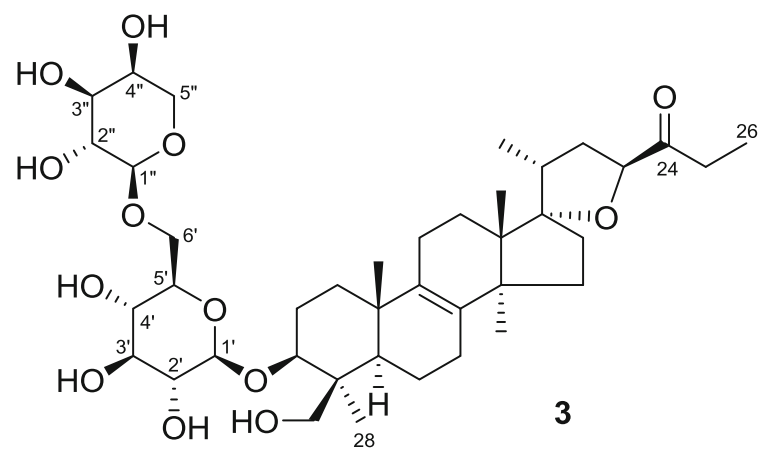<smiles></smiles>

3441,3432 and $1765 \mathrm{~cm}^{-1}$ suggested the presence of hydroxy and carbonyl functionalities, respectively. The ${ }^{1} \mathrm{H}$ NMR spectrum (Table 1) of $\mathbf{1}$ indicated signals due to four tertiary methyls $\left[\delta_{\mathrm{H}} 0.89(\mathrm{~s}), 1.01(\mathrm{~s}), 1.24(\mathrm{~s}), 1.52(\mathrm{~s})\right]$, two secondary methyls $\left[\delta_{\mathrm{H}} 1.07(\mathrm{~d}, J=6.8 \mathrm{~Hz}) ; 1.47(\mathrm{~d}\right.$, $J=7.1 \mathrm{~Hz})]$, a pair of oxygenated methylene protons $\left[\delta_{\mathrm{H}}\right.$ $3.70,4.56$ (each d, $J=11.0 \mathrm{~Hz}$ )], and two oxygenated methine protons $\left[\delta_{\mathrm{H}} 3.61(\mathrm{dd}, J=11.6,4.4 \mathrm{~Hz}) ; 4.34(\mathrm{~d}\right.$, $J=4.4 \mathrm{~Hz}$ )]. The ${ }^{13} \mathrm{C}$ NMR and DEPT spectrum (Table 1) exhibited 30 carbon signals, including an ester carbonyl resonance at $\left[\delta_{\mathrm{C}} 178.9(\mathrm{~s})\right]$, a tetra-substituted double bond at $\left[\delta_{\mathrm{C}} 135.1(\mathrm{~s}), 134.9(\mathrm{~s})\right]$, and five oxygenated carbons at [ $\left.\delta_{\mathrm{C}} 64.5(\mathrm{t}), 77.4(\mathrm{~d}), 80.0(\mathrm{~d}), 99.2(\mathrm{~s}), 117.0(\mathrm{~s})\right]$. By analyzing the above signals, especially the set of particular quaternary carbons $\left[\delta_{\mathrm{C}} 99.2,117.0,178.9\right]$ and an oxygenated methine $\left[\delta_{\mathrm{H}} 4.34(\mathrm{~d}, J=4.4 \mathrm{~Hz}) ; \delta_{\mathrm{C}} 77.4(\mathrm{~d})\right]$, compound 1 was presumed as a kind of characteristic lanostane triterpenoid derived from this genus. The above NMR spectroscopic features of $\mathbf{1}$ were very similar to those of scillasaponin D [17] and scillasaponin G [18], except lack of the signals due to the sugar moiety and an up-field shift about 10 ppm of the ${ }^{13} \mathrm{C}$ NMR signal at C-3 of $\mathbf{1}$. Based on analysis of the above spectral data, a planar structure of $\mathbf{1}$ was assumed, which was also confirmed by the HMBC (Fig. 2) correlations from $\mathrm{H}-3$ to $\mathrm{C}-1$ and C-29, from Me-19 to $\mathrm{C}-1$ and $\mathrm{C}-9$, as well as from $\mathrm{Me}-28$ and $\mathrm{H}-29$ to $\mathrm{C}-3$. 
Table 1 NMR spectroscopic data of scillascillol (1) and scillascillone (2) in pyridine- $d_{5}\left(\delta_{\mathrm{H}} 8.71, \delta_{\mathrm{C}} 149.9 \mathrm{ppm}\right)$

\begin{tabular}{|c|c|c|c|c|}
\hline \multirow[t]{2}{*}{ No. } & \multicolumn{2}{|l|}{1} & \multicolumn{2}{|l|}{2} \\
\hline & $\delta_{\mathrm{H}}$ & $\delta_{\mathrm{C}}$ & $\delta_{\mathrm{H}}$ & $\delta_{\mathrm{C}}$ \\
\hline \multirow[t]{2}{*}{1} & $1.19(\mathrm{td}, 13.3,3,4, \mathrm{H}-\alpha)$ & $35.8 \mathrm{t}$ & $1.48(\mathrm{td}, 13.1,4.4, \mathrm{H}-\alpha)$ & $37.1 \mathrm{t}$ \\
\hline & $1.69(\mathrm{dt}, 13.3,3.4, \mathrm{H}-\beta)$ & & $1.90(\mathrm{ddd}, 13.1,5.6,2.9, \mathrm{H}-\beta)$ & \\
\hline \multirow[t]{2}{*}{2} & $1.95(\mathrm{~m})$ & $29.0 \mathrm{t}$ & $2.37(\mathrm{ddd}, 14.2,4.4,2.9, \mathrm{H}-\alpha)$ & $36.3 \mathrm{t}$ \\
\hline & $2.03(\mathrm{~m})$ & & $2.86(\mathrm{td}, 14.2,5.7, \mathrm{H}-\beta)$ & \\
\hline 3 & $3.61(\mathrm{dd}, 11.6,4.4)$ & $80.0 \mathrm{~d}$ & & $214.5 \mathrm{~s}$ \\
\hline 4 & & $43.2 \mathrm{~s}$ & & $55.0 \mathrm{~s}$ \\
\hline 5 & $1.26(\mathrm{dd}, 12.8,1.6)$ & $51.5 \mathrm{~d}$ & $1.69(\mathrm{~m})$ & $53.2 \mathrm{~d}$ \\
\hline \multirow[t]{2}{*}{6} & $1.49(\mathrm{~m})$ & $18.9 \mathrm{t}$ & $1.69(\mathrm{~m})$ & $19.7 \mathrm{t}$ \\
\hline & $1.81(\mathrm{~m})$ & & $1.77(\mathrm{~m})$ & \\
\hline 7 & $1.99(\mathrm{~m})$ & $26.8 \mathrm{t}$ & $2.01(\mathrm{~m})$ & $26.5 \mathrm{t}$ \\
\hline 8 & & $135.1 \mathrm{~s}$ & & $135.9 \mathrm{~s}$ \\
\hline 9 & & $134.9 \mathrm{~s}$ & & $134.2 \mathrm{~s}$ \\
\hline 10 & & $37.2 \mathrm{~s}$ & & $37.2 \mathrm{~s}$ \\
\hline \multirow[t]{2}{*}{11} & $1.99(\mathrm{~m})$ & $21.0 \mathrm{t}$ & $2.01(\mathrm{~m})$ & $21.1 \mathrm{t}$ \\
\hline & $2.13(\mathrm{~m})$ & & $2.05(\mathrm{~m})$ & \\
\hline \multirow[t]{2}{*}{12} & $1.42(\mathrm{~m})$ & $24.9 \mathrm{t}$ & $1.44(\mathrm{~m})$ & $24.9 \mathrm{t}$ \\
\hline & $2.25(\mathrm{dt}, 13.0,9.0)$ & & $2.25(\mathrm{dt}, 13.2,8.7)$ & \\
\hline 13 & & $48.8 \mathrm{~s}$ & & $48.7 \mathrm{~s}$ \\
\hline 14 & & $50.7 \mathrm{~s}$ & & $50.7 \mathrm{~s}$ \\
\hline \multirow[t]{2}{*}{15} & 1.32 (br. t, 10.6) & $31.9 \mathrm{t}$ & 1.31 (br. t, 10.2) & $31.8 \mathrm{t}$ \\
\hline & 1.65 (br. d, 9.1) & & $1.64(\mathrm{~m})$ & \\
\hline \multirow[t]{2}{*}{16} & $1.82(\mathrm{~m})$ & $37.8 \mathrm{t}$ & $1.82(\mathrm{ddd}, 14.7,11.1,1.5)$ & $37.7 \mathrm{t}$ \\
\hline & $2.65(\mathrm{dt}, 14.5,8.9)$ & & $2.65(\mathrm{dt}, 14.7,8.9)$ & \\
\hline 17 & & $99.2 \mathrm{~s}$ & & $99.1 \mathrm{~s}$ \\
\hline 18 & $0.89(\mathrm{~s})$ & $18.7 \mathrm{q}$ & $0.90(\mathrm{~s})$ & $18.7 \mathrm{q}$ \\
\hline 19 & $1.01(\mathrm{~s})$ & $20.1 \mathrm{q}$ & $1.27(\mathrm{~s})$ & $19.6 \mathrm{q}$ \\
\hline 20 & $2.18(\mathrm{~m})$ & $43.9 \mathrm{~d}$ & $2.18(\mathrm{~m})$ & $43.9 \mathrm{~d}$ \\
\hline 21 & $1.07(\mathrm{~d}, 6.8)$ & $18.7 \mathrm{q}$ & $1.06(\mathrm{~d}, 6.8)$ & $18.7 \mathrm{q}$ \\
\hline \multirow[t]{2}{*}{22} & $2.52(\mathrm{dd}, 14.1,6.5)$ & $38.5 \mathrm{t}$ & $2.52(\mathrm{dd}, 13.9,6.5)$ & $38.4 \mathrm{t}$ \\
\hline & $2.69(\mathrm{~d}, 14.1)$ & & $2.70(\mathrm{~d}, 13.9)$ & \\
\hline 23 & & $117.0 \mathrm{~s}$ & & $117.0 \mathrm{~s}$ \\
\hline 24 & $4.34(\mathrm{~d}, 4.4)$ & $77.4 \mathrm{~d}$ & $4.35(\mathrm{dd}, 4.7,3.8)^{\mathrm{a}}$ & $77.4 \mathrm{~d}$ \\
\hline 25 & $3.27(\mathrm{~m})$ & $41.3 \mathrm{~d}$ & $3.28(\mathrm{~m})$ & $41.3 \mathrm{~d}$ \\
\hline 26 & & $178.9 \mathrm{~s}$ & & $178.8 \mathrm{~s}$ \\
\hline 27 & $1.47(\mathrm{~d}, 7.1)$ & $9.0 \mathrm{q}$ & $1.47(\mathrm{~d}, 7.1)$ & $9.0 \mathrm{q}$ \\
\hline 28 & $1.52(\mathrm{~s})$ & $23.4 \mathrm{q}$ & $1.47(\mathrm{~s})$ & $20.7 \mathrm{q}$ \\
\hline \multirow[t]{2}{*}{29} & $3.70(\mathrm{~d}, 11.0)$ & $64.5 \mathrm{t}$ & $3.85(\mathrm{~d}, 11.2)$ & $65.1 \mathrm{t}$ \\
\hline & $4.56(\mathrm{~d}, 11.0)$ & & $4.42(\mathrm{~d}, 11.2)$ & \\
\hline 30 & $1.24(\mathrm{~s})$ & $26.0 \mathrm{q}$ & $1.23(\mathrm{~s})$ & $25.9 \mathrm{q}$ \\
\hline
\end{tabular}

${ }^{a}$ Coupling constants derived from 24-OH $[7.89$ (d, 4.7)] and H-25

Taking into account its biological source and characteristic NMR data (including chemical shifts and coupling constants) of the spiro rings, the stereochemistry of $\mathbf{1}$ should be consistent with those analogues reported from this genus [8]. The hydroxy group at C-3 was equatorial $(\beta)$ according to an axial-axial coupling between $\mathrm{H}-3$ and $\mathrm{H}-2 \beta(J=11.6 \mathrm{~Hz})$ and an axial-equatorial coupling between $\mathrm{H}-3$ and $\mathrm{H}-2 \alpha$ $(J=4.4 \mathrm{~Hz})$, which was also supported by the ROESY (Fig. 2) correlations of $\mathrm{H}-3 \leftrightarrow \mathrm{H}-5$ and $\mathrm{H}-3 \leftrightarrow \mathrm{Me}-28$. Considering a relatively good rigid property of spiro rings, the determination of its stereochemistry was able to be conducted on the basis of ROESY analysis. The ROESY 


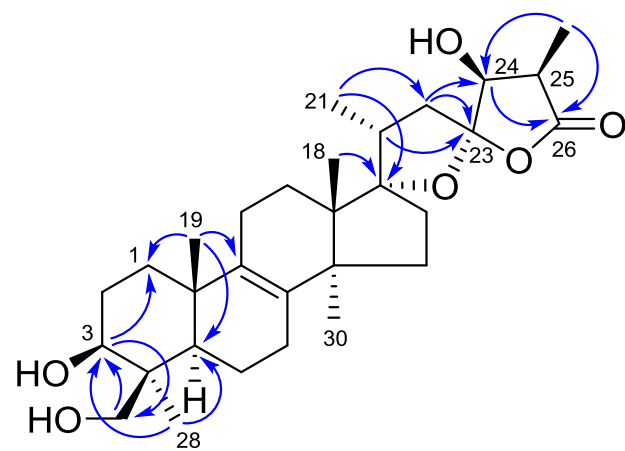

Fig. 2 Key HMBC ( $\curvearrowright$ ) and ROESY $\left({ }^{-} v\right)$ correlations of $\mathbf{1}$

correlations of $\mathrm{H}-24 \leftrightarrow \mathrm{Me}-21, \mathrm{H}-25 \leftrightarrow \mathrm{Me}-30$ and Me$30 \leftrightarrow \mathrm{H}-15 \alpha$ were indicative of $\alpha$-orientation of these protons, while the correlations of $\mathrm{Me}-18 \leftrightarrow \mathrm{H}-20 / \mathrm{H}-11 \beta$ indicative of their $\beta$-orientation. Therefore, the structure of 1 was determined as $17 \alpha, 23 \alpha$-epoxy-3 $\beta, 24 \beta, 29$-trihydroxylanost-8-en-26,23-olide and named scillascillol.

Compound 2 was isolated as a white amorphous powder. The HRESIMS (neg.) at $\mathrm{m} / z 499.3053[\mathrm{M}-\mathrm{H}]^{-}$(calcd for $\mathrm{C}_{30} \mathrm{H}_{43} \mathrm{O}_{6}, 499.3060$ ) indicated the molecular formula $\mathrm{C}_{30} \mathrm{H}_{44} \mathrm{O}_{6}$, corresponding to nine degrees of unsaturation. By comparison with the reported NMR data [17, 18], the signals of characteristic five-membered spiro rings, a tetrasubstituted double bond and six methyls were detected as before, which indicated that $\mathbf{2}$ had a very similar structure to scillascillol (1). The main difference is only that $\mathbf{2}$ had a newly arising keto carbon $\left[\delta_{\mathrm{C}} 214.5(\mathrm{~s})\right]$ instead of the oxygenated methine signal $\left[\delta_{\mathrm{H}} 3.61(\mathrm{dd}, J=11.6,4.4 \mathrm{~Hz})\right.$; $\delta_{\mathrm{C}} 80.0$ (d)] at C-3 of $\mathbf{1}$. Thus, compound 2 should be the 3 -dehydro derivative of $\mathbf{1}$. And this was confirmed by the HMBC correlations from $\mathrm{H}-1$ to C-3, C-5, C-9 and C-10, as well as from Me-28 and $\mathrm{H}-29$ to C-3, C-4 and C-5. Therefore, the structure of $\mathbf{2}$ was determined as $24 \beta, 29-$ dihydroxy-17 $\alpha, 23 \alpha$-epoxy-3-oxolanost- 8 -en-26,23-olide and named scillascillone.

Compound $\mathbf{3}$ was also obtained as a white amorphous powder, and its molecular formula was deduced to be $\mathrm{C}_{40} \mathrm{H}_{64} \mathrm{O}_{13}$ based on its negative-ion HRESIMS at $\mathrm{m} / \mathrm{z}$ $751.4261[\mathrm{M}-\mathrm{H}]^{-}$(calcd for $\left.\mathrm{C}_{40} \mathrm{H}_{63} \mathrm{O}_{13}, 751.4269\right)$. The ${ }^{1} \mathrm{H}$ NMR spectrum (Table 2) of $\mathbf{3}$ was characterized by signals due to four tertiary methyls $\left[\delta_{\mathrm{H}} 1.48(\mathrm{~s}), 1.47(\mathrm{~s})\right.$, $0.90(\mathrm{~s}), 0.87(\mathrm{~s})]$, one secondary methyl $\left[\delta_{\mathrm{H}} 1.00(\mathrm{~d}\right.$, $J=6.6 \mathrm{~Hz})], \quad$ one primary methyl $\left[\delta_{\mathrm{H}} 1.05 \quad(\mathrm{t}\right.$, $J=7.3 \mathrm{~Hz})]$, and two anomeric protons $\left[\delta_{\mathrm{H}} 4.98(\mathrm{~d}\right.$, $J=7.9 \mathrm{~Hz}) ; 4.92(\mathrm{~d}, J=7.0 \mathrm{~Hz})]$. The ${ }^{13} \mathrm{C}$ NMR spectrum (Table 2) of $\mathbf{3}$ implied the presence of a tetra-substituted double bond $\left[\delta_{\mathrm{C}} 135.2(\mathrm{~s}), 134.6(\mathrm{~s})\right]$, one keto carbonyl $\left[\delta_{\mathrm{C}} 212.6(\mathrm{~s})\right]$, and two anomeric carbons $\left[\delta_{\mathrm{C}}\right.$ 106.2 (d), 105.6 (d)]. On the other hand, a set of additional 11 oxygenated carbons were detected by comparison with

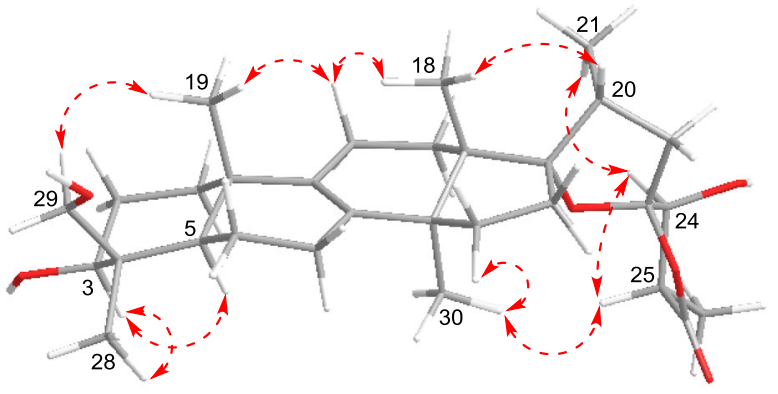

those of 15-deoxoeucosterol (4), suggesting the presence of a hexose and a pentose. The assignment of the hexose as C-6 glycosylated glucopyranosyl was launched by observation of a set of specific oxygenated carbons at $\left[\delta_{\mathrm{C}} 106.2\right.$ (d), 75.4 (d), 78.7 (d), 72.0 (d), 77.1 (d), 69.9 (t)] and a diagnostic glycosidation shift $(\Delta \approx+8$ ppm) of C-6 of glucopyranosyl. It was still supported by the detailed HMBC analysis and comparison with the reported spectral data [19]. The remaining carbons at $\left[\delta_{\mathrm{C}} 105.6(\mathrm{~d}), 72.3(\mathrm{~d})\right.$, 74.4 (d), 69.3 (d), 66.7 (t)] were established as a terminal $\alpha$ L-arabinopyranosyl unit by analysis of coupling constants of sugar moiety (Fig. 3), in which axial-axial couplings between $\mathrm{H}-1$ and $\mathrm{H}-2(J=7.0 \mathrm{~Hz})$, and between $\mathrm{H}-2$ and H-3 $(J=8.5 \mathrm{~Hz})$, and axial-equatorial coupling between $\mathrm{H}-3$ and $\mathrm{H}-4(\mathrm{~J}=2.8 \mathrm{~Hz})$ were clearly observed. And the above-mentioned NMR feature was also consistent with the reported spectral data [20, 21]. In addition, on acid hydrolysis, 3 afforded monosaccharides in the aqueous layer, which were found to be identical with authentic samples of L-arabinose and D-glucose by chiral HPLC analysis. The connection of these units was established by the HMBC correlations from the anomeric proton of the arabinopyranosyl at $\left[\delta_{\mathrm{H}} 4.92(\mathrm{~d}, J=7.0 \mathrm{~Hz})\right]$ to $\mathrm{C}-6$ of the glucopyranosyl at $\left[\delta_{\mathrm{C}} 69.9(\mathrm{t})\right]$, and from the anomeric proton of the glucopyranosyl at $\left[\delta_{\mathrm{H}} 4.98(\mathrm{~d}, J=7.9 \mathrm{~Hz})\right]$ to $\mathrm{C}-3$ of the aglycone at $\left[\delta_{\mathrm{C}} 88.9\right.$ (d)]. Thus, compound 3 was concluded to be 15 -deoxoeucosterol $3-O-\alpha$-L-arabinopyranosyl-(1 $\rightarrow$ 6)- $\beta$-D-glucopyranoside, and named scillascilloside B-1.

Compound 6, a yellow amorphous powder, had a molecular formula of $\mathrm{C}_{16} \mathrm{H}_{14} \mathrm{O}_{7}$ based on HRESIMS (neg.) at $m / z \quad 317.0665[\mathrm{M}-\mathrm{H}]^{-}$(calcd for $\mathrm{C}_{16} \mathrm{H}_{13} \mathrm{O}_{7}$, 317.0661). The ${ }^{1} \mathrm{H}$ NMR spectrum (Table 3 ) indicated the presence of two methoxy signals $\left[\delta_{\mathrm{H}} 3.72(\mathrm{~s}), 3.81(\mathrm{~s})\right]$, one aromatic methyl $\left[\delta_{\mathrm{H}} 2.66(\mathrm{~s})\right]$, two aromatic singlets $\left[\delta_{\mathrm{H}}\right.$ $6.41,6.69]$, and three low-field exchangeable proton singlets at $\left[\delta_{\mathrm{H}} 10.73,10.79,13.44\right]$. The ${ }^{13} \mathrm{C}$ NMR spectrum (Table 3) displayed a total of 16 carbon resonances ascribable to two benzene rings, two methoxy group $\left[\delta_{\mathrm{C}}\right.$ 
Table 2 NMR spectroscopic data of scillascilloside B-1 (3) in pyridine- $d_{5}\left(\delta_{\mathrm{H}} 8.71, \delta_{\mathrm{C}} 149.9 \mathrm{ppm}\right)$

\begin{tabular}{|c|c|c|c|c|c|}
\hline No. & $\delta_{\mathrm{H}}$ & $\delta_{\mathrm{C}}$ & No. & $\delta_{\mathrm{H}}$ & $\delta_{\mathrm{C}}$ \\
\hline \multirow[t]{2}{*}{1} & $1.12(\mathrm{~m})$ & $35.7 \mathrm{t}$ & 20 & $2.02(\mathrm{~m})$ & $43.7 \mathrm{~d}$ \\
\hline & $1.64(\mathrm{~m})$ & & 21 & $1.00(\mathrm{~d}, 6.6)$ & $17.3 \mathrm{q}$ \\
\hline \multirow[t]{2}{*}{2} & $2.03(\mathrm{~m})$ & $27.6 \mathrm{t}$ & 22 & $1.75(\mathrm{~m})$ & $36.9 \mathrm{t}$ \\
\hline & $2.39(\mathrm{~m})$ & & & $1.98(\mathrm{~m})$ & \\
\hline 3 & $3.50(\mathrm{dd}, 11.7,4.6)$ & $88.9 \mathrm{~d}$ & 23 & $4.63(\mathrm{dd}, 10.4,7.4)$ & $81.7 \mathrm{~s}$ \\
\hline 4 & & $44.4 \mathrm{~s}$ & 24 & & $212.6 \mathrm{~s}$ \\
\hline 5 & 1.11 (br. d, 11.7, 4.6) & $51.7 \mathrm{~d}$ & 25 & $2.54(\mathrm{~m})$ & $32.4 \mathrm{t}$ \\
\hline \multirow[t]{2}{*}{6} & $1.42(\mathrm{~m})$ & $18.7 \mathrm{t}$ & 26 & $1.05(\mathrm{t}, 7.3)$ & $7.8 \mathrm{q}$ \\
\hline & $1.75(\mathrm{~m})$ & & 28 & $1.47(\mathrm{~s})$ & $23.1 \mathrm{q}$ \\
\hline 7 & $1.99(\mathrm{~m})$ & $26.9 \mathrm{t}$ & 29 & $3.63(\mathrm{~d}, 11.1)$ & $63.2 \mathrm{t}$ \\
\hline 8 & & $135.2 \mathrm{~s}$ & & $4.45(\mathrm{~d}, 11.1)$ & \\
\hline 9 & & $134.6 \mathrm{~s}$ & 30 & $1.48(\mathrm{~s})$ & $26.5 \mathrm{q}$ \\
\hline 10 & & $36.7 \mathrm{~s}$ & $1^{\prime}$ & $4.98(\mathrm{~d}, 7.9)$ & $106.2 \mathrm{~d}$ \\
\hline \multirow[t]{2}{*}{11} & $1.90(\mathrm{~m})$ & $21.1 \mathrm{t}$ & $2^{\prime}$ & $3.95(\mathrm{dd}, 7.9,8.6)$ & $75.4 \mathrm{~d}$ \\
\hline & $2.06(\mathrm{~m})$ & & $3^{\prime}$ & $4.21(\mathrm{t}, 8.6)$ & $78.7 \mathrm{~d}$ \\
\hline \multirow[t]{2}{*}{12} & $1.40(\mathrm{~m})$ & $25.3 \mathrm{t}$ & $4^{\prime}$ & $4.12(t, 8.6)$ & $72.0 \mathrm{~d}$ \\
\hline & $2.34(\mathrm{~m})$ & & $5^{\prime}$ & $4.15(\mathrm{~m})$ & $77.1 \mathrm{~d}$ \\
\hline 13 & & $48.9 \mathrm{~s}$ & $6^{\prime}$ & $4.28(\mathrm{~m})$ & $69.9 \mathrm{t}$ \\
\hline 14 & & $50.8 \mathrm{~s}$ & & $4.92(\mathrm{~m})$ & \\
\hline \multirow[t]{2}{*}{15} & $1.38(\mathrm{~m})$ & $32.1 \mathrm{t}$ & $1^{\prime \prime}$ & $4.92(\mathrm{~d}, 7.0)$ & $105.6 \mathrm{~d}$ \\
\hline & $1.63(\mathrm{~m})$ & & $2^{\prime \prime}$ & $4.47(\mathrm{dd}, 8.5,7.0)$ & $72.3 \mathrm{~d}$ \\
\hline \multirow[t]{2}{*}{16} & $1.59(\mathrm{~m}$ & $39.8 \mathrm{t}$ & $3^{\prime \prime}$ & $4.17(\mathrm{dd}, 8.5,2.8)$ & $74.4 \mathrm{~d}$ \\
\hline & $2.16(\mathrm{~m})$ & & $4^{\prime \prime}$ & 4.31 (br. s) & $69.3 \mathrm{~d}$ \\
\hline 17 & & $97.1 \mathrm{~s}$ & $5^{\prime \prime}$ & 3.74 (br. d, 10.5) & $66.7 \mathrm{t}$ \\
\hline 18 & $0.87(\mathrm{~s})$ & $19.3 \mathrm{q}$ & & 4.30 (br. d, 10.5) & \\
\hline 19 & $0.90(\mathrm{~s})$ & $19.6 \mathrm{q}$ & & & \\
\hline
\end{tabular}

Fig. 3 Chair conformation of sugar moiety in $\mathbf{3}$

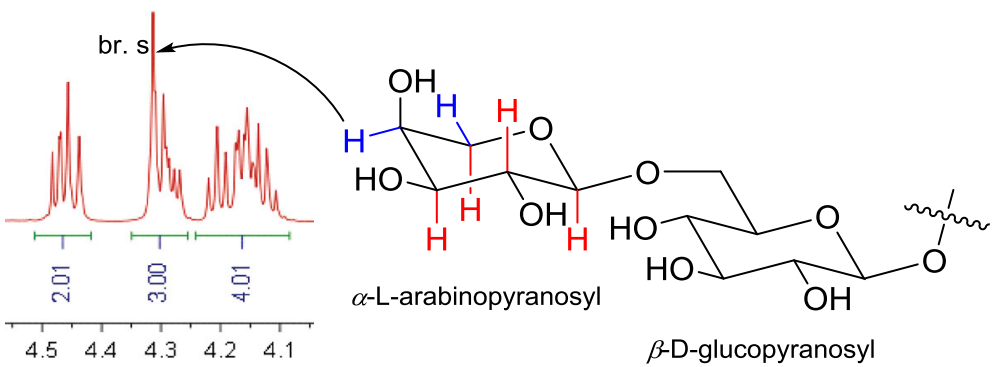

$60.0(\mathrm{q}), 60.8(\mathrm{q})]$, one methyl $\left[\delta_{\mathrm{C}} 22.8(\mathrm{q})\right]$, and one carbonyl carbon $\left[\delta_{\mathrm{C}} 182.1(\mathrm{~s})\right]$. The above NMR spectroscopic features were very similar to those of drimiopsin I [22], and the most significant difference was from an additional methoxy signal in $\mathbf{6}$. The methoxy group was positioned at $\mathrm{C}-2$ according to the $\mathrm{HMBC}$ correlations (Fig. 4) from $1-\mathrm{OH}$ at $\left[\delta_{\mathrm{H}} 13.44(\mathrm{~s})\right]$ and $2-\mathrm{OCH}_{3}$ at $\left[\delta_{\mathrm{H}}\right.$ $3.72(\mathrm{~s})]$ to $\mathrm{C}-2$ at $\left[\delta_{\mathrm{C}} 130.6(\mathrm{~s})\right]$. All of these data for $\mathbf{6}$ were consistent with the structure 2,5-dimethoxy-8methyl-1,3,6-trihydroxyxanthone.
It was worth mentioning that the ${ }^{1} \mathrm{H}$ NMR data of 6 were identical to drimiopsin D (6a) isolated by D.A. Mulholland from Drimiopsis maculata [15]. However, there were some deviation in aspect of the ${ }^{13} \mathrm{C}$ NMR data of $\mathbf{6}$ and $\mathbf{6 a}$. We believed that the ${ }^{13} \mathrm{C}$ NMR data of $\mathbf{6 a}$ should be measured in $\mathrm{CD}_{3} \mathrm{OD}$. This inference was subsequently confirmed, in view of the complete consistency of the spectral data of $\mathbf{6}$ and $\mathbf{6 a}$, when we re-tested its ${ }^{13} \mathrm{C}$ NMR using $\mathrm{CD}_{3} \mathrm{OD}$ as deuterated solvent. As a conclusion, the structure of drimiopsin $\mathrm{D}(\mathbf{6 a})$ was revised as 2,5dimethoxy-8-methyl-1,3,6-trihydroxyxanthone (6) (Fig. 5). 


\section{Experimental}

\subsection{General Experimental Procedures}

Optical rotations were measured on Jasco P-1020 or $\mathrm{SGW}_{\mathbb{B}}-3$ (INESA Instrument Co., Ltd., Shanghai, China) automatic digital polarimeter. UV data were obtained from

Table 3 NMR spectroscopic data of drimiopsin D (6)

\begin{tabular}{|c|c|c|c|c|}
\hline \multirow[t]{2}{*}{ No. } & \multicolumn{2}{|l|}{$6^{\mathrm{a}}$} & \multicolumn{2}{|l|}{$6^{\mathrm{b}}$} \\
\hline & $\delta_{\mathrm{H}}$ & $\delta_{\mathrm{C}}$ & $\delta_{\mathrm{H}}$ & $\delta_{\mathrm{C}}$ \\
\hline 1 & & $154.6 \mathrm{~s}$ & & $155.9 \mathrm{~s}$ \\
\hline 2 & & $130.6 \mathrm{~s}$ & & $131.9 \mathrm{~s}$ \\
\hline 3 & & $158.0 \mathrm{~s}$ & & $158.9 \mathrm{~s}$ \\
\hline 4 & $6.41(\mathrm{~s})$ & $93.5 \mathrm{~d}$ & $6.37(\mathrm{~s})$ & $94.4 c$ \\
\hline $4 a$ & & $151.7 \mathrm{~s}$ & & $153.3 \mathrm{~s}$ \\
\hline 5 & & $132.8 \mathrm{~s}$ & & $134.2 \mathrm{~s}$ \\
\hline 6 & & $155.2 \mathrm{~s}$ & & $156.4 \mathrm{~s}$ \\
\hline 7 & $6.69(\mathrm{~s})$ & $116.0 \mathrm{~d}$ & $6.61(\mathrm{~s})$ & 116.8 \\
\hline 8 & & $136.2 \mathrm{~s}$ & & $138.5 \mathrm{~s}$ \\
\hline $8 a$ & & $111.1 \mathrm{~s}$ & & $113.0 \mathrm{~s}$ \\
\hline 9 & & $182.1 \mathrm{~s}$ & & $183.9 \mathrm{~s}$ \\
\hline $9 a$ & & $102.3 \mathrm{~s}$ & & $104.1 \mathrm{~s}$ \\
\hline $10 \mathrm{a}$ & & $151.7 \mathrm{~s}$ & & $153.7 \mathrm{~s}$ \\
\hline $8-\mathrm{CH}_{3}$ & $2.66(\mathrm{~s})$ & $22.8 \mathrm{q}$ & $2.70(\mathrm{~s})$ & 23.3 \\
\hline $2-\mathrm{OCH}_{3}$ & $3.72(\mathrm{~s})$ & $60.0 \mathrm{q}$ & $3.85(\mathrm{~s})$ & 60.9 \\
\hline $5-\mathrm{OCH}_{3}$ & $3.81(\mathrm{~s})$ & $60.8 \mathrm{q}$ & $3.90(\mathrm{~s})$ & 61.7 \\
\hline $1-\mathrm{OH}$ & $13.44(\mathrm{~s})$ & & & \\
\hline $3-\mathrm{OH}$ & 10.79 (br. s) & & & \\
\hline $6-\mathrm{OH}$ & 10.73 (br. s) & & & \\
\hline
\end{tabular}

a Measured in DMSO- $d_{6}\left(\delta_{\mathrm{H}} 2.49, \delta_{\mathrm{C}} 39.5 \mathrm{ppm}\right)$

b Measured in $\mathrm{CD}_{3} \mathrm{OD}\left(\delta_{\mathrm{H}} 3.30, \delta_{\mathrm{C}} 49.0 \mathrm{ppm}\right)$

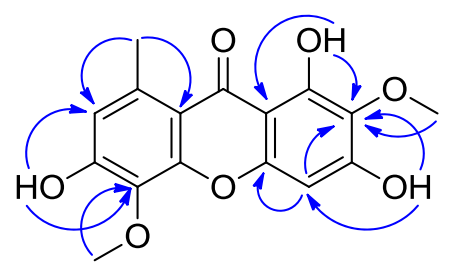

Fig. 4 Key HMBC ( $\frown$ ) correlations of 6
HPLC online analysis. IR spectra $(\mathrm{KBr})$ were obtained on a Bruker Tensor-27 infrared spectrophotometer. NMR spectra were carried out on a Bruker Avance III 600 or Bruker AV-400 (Bruker BioSpin GmbH, Rheinstetten, Germany) spectrometer with deuterated solvent signals used as internal standards. ESIMS and HRESIMS were measured using Bruker HCT Esquire 3000 and API QSTAR time-offlight mass spectrometers, respectively. Silica gel (200-300 mesh, Qingdao Marine Chemical Inc., China), MCI gel CHP-20P (75-150 $\mu \mathrm{m}$, Mitsubishi Chemical Corporation, Japan), Chromatorex C-18 (40-75 $\mu \mathrm{m}$, Fuji Silysia Chemical Ltd., Japan) and Sephadex LH-20 (Amersham Biosciences, Sweden) were used for column chromatography. Fractions were monitored and analyzed using TLC, in combination with Agilent 1200 series HPLC system equipped by Extend-C18 column $(5 \mu \mathrm{m}, 4.6 \times 150 \mathrm{~mm})$. A TCI Chiral MB-S column $(5 \mu \mathrm{m}, 4.6 \times 250 \mathrm{~mm}$, Tokyo Chemical Industry Co., Ltd., Tokyo, Japan) was applied for determination of acid hydrolyzates using Agilent 1200 series HPLC system with an external Alltech 3300 ELSD detector (Grace, Deerfield, USA).

\subsection{Plant Material}

The whole plants of $S$. scilloides were collected from He County of Anhui Province, China, in August 2009, and identified by Prof. Shou-Jin Liu of Anhui University of Chinese Medicine. A voucher specimen (No. BBP0208018SS) was deposited at BioBioPha Co., Ltd.

\subsection{Extraction and Isolation}

The dried and crushed whole plants of $S$. scilloides $(9.5 \mathrm{~kg})$ were extracted with EtOH- $\mathrm{H}_{2} \mathrm{O}(95: 5, \mathrm{v} / \mathrm{v} ; 3 \times 18 \mathrm{~L}$, each 7 days) at room temperature, and the solvent was removed under reduced pressure to give crude extract (ca. $1.9 \mathrm{~kg}$ ), which was fractionated by silica gel CC successively eluted with a gradient of increasing acetone in petroleum ether (PE) $(15: 1,10: 1,7: 1,4: 1,2: 1,1: 1,0: 1 ; \mathrm{v} / \mathrm{v})$ and then $\mathrm{MeOH}$ to afford fractions $\mathrm{A}-\mathrm{H}$, respectively. Fraction $\mathrm{B}$ was isolated by Sephadex $\mathrm{LH}-20 \mathrm{CC}\left(\mathrm{CHCl}_{3} / \mathrm{MeOH} ; 1: 1\right)$ and repeated silica gel $\mathrm{CC}\left(\mathrm{CHCl}_{3} / \mathrm{MeOH} ; 100: 0 \rightarrow\right.$ 100:1) to yield 5 (181 mg). Fraction $C$ was further

Fig. 5 Structure revision of drimiopsin D<smiles>COc1c(O)cc(O)c2c(=O)c3c(C)[14cH]c(O)c(OC)c3oc12</smiles>

$6 a$<smiles>COc1c(O)cc2oc3c(OC)c(O)cc(C)c3c(=O)c2c1O</smiles> 
separated by silica gel $\mathrm{CC}\left(\mathrm{CHCl}_{3} / \mathrm{MeOH} ; 100: 1 \rightarrow 20: 1\right)$, Sephadex LH-20 (MeOH) and preparative TLC (PE/ EtOAc; $8: 1)$ to provide $2(49 \mathrm{mg}), 4(474 \mathrm{mg})$ and 8 $(45 \mathrm{mg})$. Fraction D was applied repeatedly to RP-18 CC $\left(\mathrm{MeOH} / \mathrm{H}_{2} \mathrm{O} ; 60 \rightarrow 90 \%\right)$ and then by Sephadex LH-20 $(\mathrm{MeOH})$ to afford $\mathbf{1}(40 \mathrm{mg}), \mathbf{6}(127 \mathrm{mg})$ and $7(116 \mathrm{mg})$. Compound $\mathbf{3}(291 \mathrm{mg})$ was eventually acquired by means of repeated silica gel $\mathrm{CC}\left(\mathrm{CHCl}_{3} / \mathrm{MeOH} ; 30: 1 \rightarrow 10: 1\right)$, RP-18 $\left(\mathrm{MeOH} / \mathrm{H}_{2} \mathrm{O} ; 40 \rightarrow 70 \%\right)$ and Sephadex LH-20 $\left(\mathrm{CHCl}_{3} / \mathrm{MeOH} ; 1: 1\right)$ from the fraction $\mathrm{F}$.

\subsection{Scillascillol (1)}

White amorphous powder; $[\alpha]_{\mathrm{D}}^{25}-0.7[c \quad 0.42, \mathrm{MeOH}-$ $\mathrm{CHCl}_{3}$ (1:1)]; IR (KBr) v vax: 3441, 3432, 2943, 2880, 1765, 1631, 1455, 1374, 1321, 1116, 1036, 997, 944, $923 \mathrm{~cm}^{-1}$; ${ }^{1} \mathrm{H}$ and ${ }^{13} \mathrm{C}$ NMR data: see Table 1; ESIMS (pos.): $\mathrm{m} / z \quad 525[\mathrm{M}+\mathrm{Na}]^{+}$; HRESIMS (neg.): $\mathrm{m} / \mathrm{z}$ $501.3207[\mathrm{M}-\mathrm{H}]^{-}$(calcd for $\mathrm{C}_{30} \mathrm{H}_{45} \mathrm{O}_{6}, 501.3216$ ).

\subsection{Scillascillone (2)}

White amorphous powder; $[\alpha]_{\mathrm{D}}^{25}+46.0(c 0.25, \mathrm{MeOH})$; IR (KBr) $v_{\max }: 3471,2960,2943,1765,1702,1639,1456$, 1381, 1320, 1115, 1046, 998, 943, $923 \mathrm{~cm}^{-1} ;{ }^{1} \mathrm{H}$ and ${ }^{13} \mathrm{C}$ NMR data: see Table 1; ESIMS (pos.): $\mathrm{m} / z$ $[\mathrm{M}+\mathrm{Na}]^{+}$; HRESIMS (neg.): $\mathrm{m} / z 499.3053[\mathrm{M}-\mathrm{H}]^{-}$ (calcd for $\mathrm{C}_{30} \mathrm{H}_{43} \mathrm{O}_{6}, 499.3060$ ).

\subsection{Scillascilloside B-1 (3)}

White amorphous powder; $[\alpha]_{\mathrm{D}}^{25}-57.9(c 0.30, \mathrm{MeOH}) ; \mathrm{IR}$ (KBr) $v_{\max }: 3440,2940,2883,1774,1725,1713,1633$, 1456, 1376, 1255, 1078, 1048, 1010, $755 \mathrm{~cm}^{-1} ;{ }^{1} \mathrm{H}$ and ${ }^{13} \mathrm{C}$ NMR data: see Table 2; ESIMS (pos.): $\mathrm{m} / \mathrm{z} 775$ $[\mathrm{M}+\mathrm{Na}]^{+}$; HRESIMS (neg.): $\mathrm{m} / z 751.4261[\mathrm{M}-\mathrm{H}]^{-}$ (calcd for $\mathrm{C}_{40} \mathrm{H}_{63} \mathrm{O}_{13}, 751.4269$ ).

\subsection{2,5-Dimethoxy-8-methyl-1,3,6-trihydroxyxanthone (= drimiopsin $\mathrm{D}, \mathbf{6})$}

Yellow amorphous powder; UV (MeOH) $\lambda_{\max }: 247,276$ (sh), $321 \mathrm{~nm}$; IR (KBr) $v_{\max }$ : 3443, 2959, 2849, 1650, 1619, 1579, 1513, 1461, 1320, 1292, 1267, 1186, 1162, 1105, 992, 816, $796 \mathrm{~cm}^{-1} ;{ }^{1} \mathrm{H}$ and ${ }^{13} \mathrm{C}$ NMR data: see Table 3; ESIMS (pos.): $\mathrm{m} / z, 341[\mathrm{M}+\mathrm{Na}]^{+}$; HRESIMS (neg.): $\mathrm{m} / \mathrm{z} 317.0665[\mathrm{M}-\mathrm{H}]^{-}$(calcd for $\mathrm{C}_{16} \mathrm{H}_{13} \mathrm{O}_{7}$, 317.0661).

\subsection{Acid Hydrolysis of $\mathbf{3}$}

Compound 3 ( $3 \mathrm{mg}$ ) was heated in $2 \mathrm{M} \mathrm{HCl}(3 \mathrm{~mL})$ at a temperature of $45^{\circ} \mathrm{C}$ for $4 \mathrm{~h}$. After cooling, the reaction mixture was neutralized with $\mathrm{KOH}$ to a $\mathrm{pH}$ of approximately 7, and then extracted with EtOAc. The aqueous layer was analyzed by HPLC under the following conditions: solvent, n-hexane/isopropanol (85:15); flow rate, $1.0 \mathrm{ml} / \mathrm{min}$; temperature, $25^{\circ} \mathrm{C}$. The retention times $\left(t_{\mathrm{R}}\right)$ of D-glucose and L-arabinose were 5.5 and $6.9 \mathrm{~min}$, respectively.

Acknowledgments This work was financially supported by "Largescale Compound Library" project of National Development and Reform Commission of China.

\section{Compliance with Ethical Standards}

Conflict of interest The authors declare no conflict of interest.

Open Access This article is distributed under the terms of the Creative Commons Attribution 4.0 International License (http:// creativecommons.org/licenses/by/4.0/), which permits unrestricted use, distribution, and reproduction in any medium, provided you give appropriate credit to the original author(s) and the source, provide a link to the Creative Commons license, and indicate if changes were made.

\section{References}

1. M. Pfosser, F. Speta, Ann. Missouri Bot. Gard. 86, 852-875 (1999)

2. M.Y. Fan, Y.M. Wang, Z.M. Wang, H.M. Gao, Chin. J. Chin. Mater. Med. 39, 162-170 (2014)

3. I. Kouno, N. Noda, Y. Ida, M. Sholichin, K. Miyahara, T. Komori, T. Kawasaki, Liebigs Ann. Chem. 1982, 306-314 (1982)

4. M. Sholichin, K. Miyahara, T. Kawasaki, Heterocycles 17, 251-257 (1982)

5. M. Sholichin, K. Miyahara, T. Kawasaki, Chem. Pharm. Bull. 33, 1756-1759 (1985)

6. S.M. Lee, H.K. Chun, C.H. Lee, B.S. Min, E.S. Lee, Y.H. Kho, Chem. Pharm. Bull. 50, 1245-1249 (2002)

7. Y. Nishida, M. Eto, H. Miyashita, T. Ikeda, K. Yamaguchi, H. Yoshimitsu, T. Nohara, M. Ono, Chem. Pharm. Bull. 56, 1022-1025 (2008)

8. M. Ono, D. Toyohisa, T. Morishita, H. Horita, S. Yasuda, Y. Nishida, T. Tanaka, M. Okawa, J. Kinjo, H. Yoshimitsu, T. Nohara, Chem. Pharm. Bull. 59, 1348-1354 (2011)

9. M. Ono, Y. Takatsu, T. Ochiai, S. Yasuda, Y. Nishida, T. Tanaka, M. Okawa, J. Kinjo, H. Yoshimitsu, T. Nohara, Chem. Pharm. Bull. 60, 1314-1319 (2012)

10. M. Ono, T. Ochiai, S. Yasuda, Y. Nishida, T. Tanaka, M. Okawa, J. Kinjo, H. Yoshimitsu, T. Nohara, Chem. Pharm. Bull. 61, 592-598 (2013)

11. F. Wang, Y. Gao, L. Zhang, B. Bai, Y.N. Hu, Z.J. Dong, Q.W. Zhai, H.J. Zhu, J.K. Liu, Org. Lett. 12, 3196-3199 (2010)

12. F. Wang, Y.J. Li, F.C. Ren, G.Z. Wei, J.K. Liu, Chem. Pharm. Bull. 59, 484-487 (2011)

13. F. Wang, D.S. Zhou, G.Z. Wei, F.C. Ren, J.K. Liu, Phytochemistry 77, 312-317 (2012)

14. F. Wang, X.L. Li, G.Z. Wei, F.C. Ren, J.K. Liu, Nat. Prod. Bioprospect. 3, 238-242 (2013)

15. D.A. Mulholland, C. Koorbanally, N.R. Crouch, P. Sandor, J. Nat. Prod. 67, 1726-1728 (2004)

16. A. Abdel-Lateff, C. Klemke, G.M. König, A.D. Wright, J. Nat. Prod. 66, 706-708 (2003) 
17. Y. Mimaki, S. Kubo, Y. Kinoshita, Y. Sashida, L.G. Song, T. Nikaido, T. Ohmoto, Phytochemistry 34, 791-797 (1993)

18. K. Ori, M. Koroda, Y. Mimaki, H. Sakagami, Y. Sashida, Phytochemistry 64, 1351-1359 (2003)

19. H.T. Nguyen, G.Y. Song, J.A. Kim, J.H. Hyun, H.K. Kang, Y.H. Kim, Bioorg. Med. Chem. Lett. 20, 309-314 (2010)
20. D.C. Albach, C.H. Gotfredsen, S.R. Jensen, Phytochemistry 65, 2129-2134 (2004)

21. T. Kanchanapoom, Phytochemistry 68, 692-696 (2007)

22. Y.B. Zhuang, H. Yin, X.W. Zhang, W. Zhou, T. Liu, Helv. Chim. Acta 98, 699-703 (2015) 